から年間予約で一種でも自費購読するととを おす〉ぬする。10 年, 20 年とそれが堆積す れば，それは既に一つの財産となる。そして 銀行へ和金を預金するよりは, 利迴りからん つても数等上であるととは，今日までの多く の学者の体験が明らかに示している事実であ る。

雑誌もよいが, そら沢山の専門雑誌全部に は到底目を通せるものではない。何とか便法 はないかとは誰でも感ずる所である。そてで 日本でも外国でもいろいろの抄録雑誌が出て らる。日本のは「医学中央雑誌」と名づけら れ, 恐らく日本の全医学雑誌の中で最権威 のあるものであろう。酒は少し高いが，如何 なる研究室にも必ず一部は備えつけるべき必 要品である。発表の時期より少し遅れるが, とれを参照すれば, 全日本の医学者の研究題 目とその内容がわかる。

外国では各科に Zentralblatt, Berichte, Review, Zentralorgan, Abstracts の名で出 ており, Chemical Abstracts Service with Indexes は最有名で，一年の購読料は 15 万円である。オランダでは各科別の Excerpta Medica が出版され，18 部門になつているの で便利である。

その他毎年の進歩を各学科について述べた 年報と称するものも沢山ある。Jahresberichte, Year Book, Recent Advances, Annual
Review などの名がある。最も有名で利用価 值の高いものは Annual Review of Biochemistry であろ5。Advances in Cancer Research の如きも既に第 4 巻まで出ている。 これらの雑誌乃至定期刊行物は一つの医学 図書館では予算が限られているから, 出来る だけ沢山とりたいのは山々であるが，思らに 任せないのが実情である。そとで利用価值の 多い雑誌は各館ともとるが, 利用価值は少い が時々見たい雑誌は，なるべく地区の数館が 手分けして，どては何を，他は又ほかのをと， 別々のをとつて, 互いに貸借する（近頃はフ イルムで) 方法が最も有利であると思ら。そ れには各館が現在どのような雑誌 (海外の) を注文しているかがわかる一覧表が质しい。 多ちろん Back Number についての調查多必 要で, 今や医学図書館協会でやりつつあるが Current List \&とれに負けず必要ではない か。何とか中央事務局の损折で, 年一回の 総会の時に現在購読中の外国雑誌のリストを もちょり，中央事務局の編集で，每年一回ず つ全日本の Current List が出来たら, 本年 は全日本の医科大学図書館が協会に加盟する といらととであるから，すべての研究者の利 便は測り知れない\&のがあると思う。協会創 立 30 年記念の事業として, 本年より開始を 切望する。

\title{
全国大学図書館における文献相互利用 申込書の統一について
}

松 本 亀 吉*

近年光学機械の発達と共に, 罒書館相互に おける相互貸借図畫に代り, マイクロフィル ムによる文献複写の利用が盛んになり, 文献 資料の少ない図書館は, 必要文献を容易に入

* 徳島大学医学図書館
手するととがでをるよらになり，研究者の研 究を助長し, 我が国学術研究に寄与するとと ろ甚大なものが御座います。

医学図書館協会加盟館は勿論, 薬学図書館 協議会等に沶かれましても, 逐次相互貸借図 書に代り, 文献複写の利用が年々増加の一途 
をたどつているととと存じます。当館と和け る昨年度の文献相互利用の統計によります と, 申込総件数は, 1620 件で, 相互貸借図 書の申込は, 116 件に対し, フィルム複写の 申込は，1520 件の多きに及んでおり，文献 相互利用に要した経費は，197,659 円に達し ております。

文部省におかれても，文献資料の複写によ る保存と, 効率的利用の重要性を認められ, 10 大学図書館 (北大, 東北大, 東大, 東工大, 名大, 金沢大, 京大, 阪大, 広大, 九大）を マイクロ・センター館に指定されており，そ の活潑な発展と運営が期待されております。

現在学術研究に必要な文献資料は, その所 蔵個所さえ判れば, 大学図書館であれ, 研究 所, 病院, 会社等に称かれして夕, 文献の 申込に対しましては, 誠に親切に申込に応じ て下され，100\% 入手するととができるよう になりました。尚国内に所蔵されていない医 学関係の文献は, 東北大学医学図書館の献身 的な奉仕により，海外より入手するととがで き, 我が国医学の進展に貢献すととろ大なも のが御座います。

図書館に和ける文献相互利用は, 時代の要 求とはいえ, 文献複写業務に必要な, 人的, 予算的裏付け夕なされないにも拘らず，乙の よ5に発展しつつあるととは, 四書館人が縁 の下の力持ちとして, 幾分なりとも社会の発 展に寄与せんとする, 積極的な奉仕精神の発 露に外ならないと存じます。また図畫館相互 における文献利用の円滑な運営は, セクショ ナリズムを排し，図畫館人であるといら相互 の近親感と信頼感に加え, 奉仕的精神のしか らしむるところと存じます。

現在図書館に打ける文献相互利用は，一協 会，一協議会，一ブロックの関係者のみの利 用に限らず，全国的いな世界的に発展しつつ あるのではないでしょらか。然るに文献相互 利用の出発点たるべき, 申込書の現状は如何 でしょう。文献相互利用の全国的利用に発展 しつつある過程においては, 無理からぬとと と存じますが，わが国に利ける相互貸借図畫
の創始たる，医学図書館協会におかれまして 8, 文献複写の申込書様式は正式に規定され ておらず，相互貸借図書申込書を兼用してお

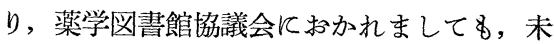
だ決定を見ないのではないでしよらか。10大 学図書館のマイクロ・センタ一館に挑かれま しても, センタ一館共通の申込書様式はなく, 各館独自の様式を使用しておられるのではな いでしよらか。また医学図書館と関係の深い A. B. C.C. (アメリカ原爆傷害調查委員会) におかれても, 独自の申达書を採用しておら れます。

とのように協会, 協議会, センタ一館, 各 ブロックにおいて，思い思々の申込書を使用 され，事務整理の都合上，指定の申込書によ らざれば，文献相互利用が出来ないよ5にで 岁れば，各種の申込書を印刷用意しておか ねばならず，経費の浪費となり，全国的な文 献相互利用の円滑を欠く恐れがあり，わが国 学術研究の進展飞寄与する, 文献相互利用の 健全な発展を阻害するととになるのではない でしよらか。

願わくば，文献相互利用の基礎が全国的利 用にまで至つて执らない現在, 医学図書館協 会, 薬学図書館協議会, マイクロ・センター 運営委員会等におかれまして, 御協議の上わ が国文献相互利用の発展の基礎を築く第一歩 として, 全国大学図書館共通の, 文献相互利 用申込畫の様式を決定して頂きたりもので す。

文献相互利用の規定等につきましては，自 然科学関係図書館, 人文, 社会科学関係図書 館等による, 文献利用の相違もあり早急な統 一は無理と存じますが, 申込書の統一は関係 団体の努力により不可能ではないと愚考致し ます。

申込書の統一により,申込手続は簡素化さ れ, 事務能率は向上し全国的文献相互利用8 容易になり,わが国学術研究の進展に寄与す ると共に, 文献相互利用の発展を促し, 図書 館奉仕の成果を一般に認識させるに至らしむ るのではないでしようか。 